\title{
Seismology in India
}

\author{
B K RASTOGI* \\ Institute of Seismological Research, Raisan, Gandhinagar 382 009, India
}

(Received on 16 April 2016; Accepted on 15 June 2016)

\begin{abstract}
Recent seismological research in India can be mainly grouped into study of 1) seismogenesis and seismotectonics of the three regions viz., Himalaya, Andaman-Nicobar subduction zone and the Stable Continental region (SCR); 2) Strong motion study and 3) earthquake prediction. Last few years have witnessed significant change in monitoring of earthquakes through about hundred broadband seismographs in National Network and many more in clusters whose data are brought online to two centers at National Centre for Seismology, Delhi and INCOIS, Hyderabad. Extensive research on reservoir induced earthquakes has culminated into "Deep Crustal Drilling" (DCD) in the Koyna-Warna region down to focal depth to understand the nucleation and generation process of earthquakes.
\end{abstract}

Keywords: Seismotectonics; Himalaya; Andaman Subduction zone; Deep Crustal Drilling; Earthquake Hazard and Precursors

\section{Introduction}

Ministry of Earth Sciences (MoES) \& Department of Science and Technology, Government of India are the major funding agencies. A new National Center for Seismology (NCS) has been started under MoES in New Delhi by taking out the Seismology Division of India Meteorological Department (IMD). Geological Survey of India (GSI) carries out intensity surveyes and site response studies. Various research institutes involved in seismological research are National Geophysical Research Institute (NGRI, Hyderabad); Institute of Seismological Research (ISR, Gandhinagar, Gujarat); Wadia Institute of Himalayan Geology (WIHG, Dehradun, Uttrakhand); Northeast Institute of Science \& Technology (NEIST, Jorhat, Assam); Centre for Mathematical Modeling and Computer Simulation (CMMACS, Bangalore). Various universities carrying out seismological research are - IITs at Kharagpur; Roorkee, Kanpur and Mumbai; IISc, Bangalore; Universities of Delhi, Jadavpur, Krukshetra, Manipur University (Imphal), Osmania University (Hyderabad), Benaras Hindu University (BHU) and Indian Schools of Mines (Dhanbad).

Seismological and geodetic networks in the
Himalayan region have provided vital information on the seismicity, seismogenesis, tectonic processes in the region, crustal structure, role of fluids in earthquake occurrence, delineation of shallow structures and about various features of the tectonic domains in the Himalaya. Strong motion data have been used to estimate the attenuation relation. It has been found that the earthquakes in Himalaya occur along a narrow belt, and are influenced by the subsurface ridges on the under-thrusting Indian plate. GPS data, on the other hand, has provided evidence for strain accumulation, spatial extent of locked region and the convergence rate. Seismological waveform data have been used to delineate the deep seismic structure of the Indian shield, western Himalaya, Ladakh, Tibet, Arunachal Himalaya and eastern Himalaya syntaxis.

Seismological research in India got special impetus during 2011-2015 because of great thrust given to seismological monitoring and getting the data online at Delhi and Hyderabad from over hundred broadband seismograph stations of NCS, NEIST, WIHG and ISR. The recent seismological research in India focus on, 1) studies on seismogenesis and seismotectonics (distinctly divided into regions of Himalaya, Andaman-Nicobar subduction zone Stable

\footnotetext{
*Author for Correspondence: E-mail: bkrastogi12@ gmail.com
} 
Continental region (SCR); 2) studies on seismic hazard, microzonation and risk; 3) research on earthquake prediction. Outstanding work from India on reservoir induced earthquakes including multi-disciplinary studies in Koyna-Warna region has been reported. As the earthquakes in this region are occurring at 2$8 \mathrm{~km}$ depth it was possible to look into the focal zone by deep drilling to unravel the hidden mystery involved with reservoir induced earthquake nucleation and generating processes. Drilling to over a $\mathrm{km}$ has been completed. Hard Deccan Trap were encountered down to about $900 \mathrm{~m}$ resting over basement rock without any sedimentary layer.

\section{Seismic Monitoring}

\section{National Network}

India has real time seismic monitoring, information dissemination and archival system through SMS, FAX, email, IVRS under the National Centre for Seismology (NCS). The country-wide network consists of 84 seismological observatories. Data of all these stations of the national network and telemetry clusters is received at Indian National Centre of Ocean Information Services and NCS. In addition to this network there are a few more networks which are operated by a few academic and research institutes and some of them are also connected through VSAT to NCS and INCOIS.

\section{V-SAT Based Telemetry Clusters}

A network of 60 broadband seismographs and strong motion accelerographs is run by the Institute of Seismological Research (ISR), Gandhinagar in Gujarat including a sub-network at Sardar Sarovar reservoir area. V-SAT based telemetry cluster (16 stations) in Delhi and in Northeast India (20 stations) are run by NCS. Another network (15 stations) in NE India is by Northeast Institute for Science and Technology (NEIST), Jorhat. National Geophysical Research Institute, Hyderabad has a network in Koyna, Wadia Institute of Himalayan Geology, Dehradun operates a network in Garhwal (10 stations) and in NW Himalaya and the Bhaba Atomic Research Centre, Mumbai operates a network in Gauribidanur, Karnataka. These networks typically include about a dozen broadband seismographs individually.

\section{Organizations Operating Stand-Alone Seismic Stations/Networks}

National Geophysical Research Institute maintains over 50 stations at different locations in NE India, Peninsular India and Andaman Islands. One to five broadband seismographs are run by Indian Institute of Geomagnetism, Mumbai; Geological Survey of India, Kolkata; National Institute of Rock Mechanics, Kolar; Central Scientific Instruments Organisation, Chandigarh; Centre for Earth Science Studies, Tiruvananthapuram; Maharashtra Engineering Research Institute; Kerala State Electricity Board, Nat. Hydroelectric Power Corp.; IITs-Roorkee/ Kharagpur; Manipur University, Imphal; Indian School of Mines, Dhanbad; Kurukshetra University; Kumaun University, Jammu University etc.

\section{Geodetic Deformation from GPS Measurements}

NGRI, Survey of India, CMMACS, IIG, WIHG, ISR and a few other institutes have been maintaining several GPS stations. Many of these stations are connected through VSAST and the data are collated at NCS and INCOIS. Permanent stations include over about 20 in peninsular India, 15 in Andaman Nicobar region, 30 in Himalayan arc, 10 in Indo-Burmese arc. Some 25 stations are in Gujarat. Besides these permanent stations, several institutes are involved in campaign mode studies.

Global Position System data shows Indian plate movement of $5 \mathrm{~cm} /$ year in the NE direction. In the north the convergence rates between India and southern Tibet is $11 \pm 1 \mathrm{~mm} / \mathrm{y}$ in the arc normal and + $5 \mathrm{~mm} / \mathrm{y}$ dextral in Kashmir (Schiffman et al., 2013; Kundu et al., 2014), $15 \mathrm{~mm} / \mathrm{yr}$ in the northwest Himalaya (Banerjee and Burgmann, 2002), $18 \mathrm{~mm} /$ yr in Garhwal-Kumaun Himalaya, $20.5 \mathrm{~mm} / \mathrm{year}$ in western Nepal, $17.8 \pm 0.5 \mathrm{~mm} /$ year in central and east Nepal (Ader et al. 2012), and $16 \mathrm{~mm} / \mathrm{yr}$ in NE Himalaya. Study by Mukul et al. (2010) indicate that the convergence is being accommodated in the NE Himalayan wedge at a rate of about $15-20 \mathrm{~mm} / \mathrm{yr}$ and approximately $1.5-3.5 \mathrm{~mm} / \mathrm{yr}(\sim 10-20 \%)$ of the present-day convergence in the NE Himalayan wedge is being accommodated in the Shillong Plateau.

Detailed analysis of seismicity and the recently acquired GPS data in northeast India provide evidence for present day active deformation front (the plate 
boundary fault) between the India and Burma plates. Majority of the earthquakes are of interplate type within the subducted Indian plate which is dragged northward along this predominantly strike-slip plate boundary. It is now suggested that the Churachandpur-Mao Fault (CMF), a geologically older thrust fault, accommodates motion of about 16 $\mathrm{mm} /$ year through dextral strike-slip manner. The motion across the CMF constitutes about $43 \%$ of the relative plate motion of $36 \mathrm{~mm} /$ year between the India and Sunda plates. The remaining motion is accommodated at the Sagaing Fault (SF) in central Burma. On the basis of modeling which suggests low friction along the CMF, absence of low-magnitude seismicity along the CMF, lack of historic major earthquakes at the CMF zone and geological field investigations, it is proposed that the motion across the CMF occurs predominantly in an aseismic manner (Kundu et al., 2013). An analysis of the recent seismicity data from the Andaman-Sumatra region suggests that the seismic activation started in the middle of July 2000 (about 4.5 years before the 2004 Mw 9.3 earthquake). This includes an increase in the background seismicity rates, particularly in the southern part of the seismogenic zone near the epicenter. The GPS data acquired before the 2004 Sumatra-Andaman mega thrust earthquake Mw 9.3 also support strain accumulation in the region corresponding to a slip deficit rate of about $3 \mathrm{~cm} /$ year.

Two great earthquakes of 2012, 100km west of the Sumatra subduction zone are associated with strike-slip faulting due to differential plate motion in between them. The coseismic offsets at several GPS sites around the epicentre are consistent with the finite-fault slip models derived from back projection of the seismic waves recorded by the global networks. Monitoring of crustal deformation using GPS suggests that currently the post-seismic deformation is quite intense in the southern Andaman, Nicobar and Sumatra region. Evidence from paleotsunami investigations suggest that great earthquakes occurred in the past.

GPS measurements have been used to understand the plate motion of the Indian plate, internal deformation or the rigidity of the plate. It is found that the Indian plate moves north-eastward at the rate of $\sim 5 \mathrm{~cm} /$ year, and the major Narmada-Son-Tapti fault system does not segment the motion. The localised deformation is consistent with the view that seismicity migrates and deformation rate changes with time.

Around the hypocenter of $2001 \mathrm{Mw} 7.7$ Kachchh earthquake a high velocity and rigid mafic intrusive body has been inferred in a large zone which accumulates high stress/strain. The Bhuj earthquake nucleated from a fluid filled zone at depths of 15-25 $\mathrm{km}$. Kachchh region has significant horizontal deformation that can cause earthquakes. However, there is unusually high uplift up to $2 \mathrm{~cm} / \mathrm{y}$ as revealed by GPS and DInSAR data (Rastogi et al., 2012, 2014).

\section{Tectonics of the Indian Region}

Indian plate is defined by Indus-Tsangpo suture in the north bordering Himalaya, the left-slip Chaman fault in the west, the right-slip Sagaing fault in the east and continuing southward along Andaman Islands and Sumatra-Java Arc. A large part of the convergence of India and Eurasia is accommodated along the Himalaya arc and the rest is transferred to the north which is responsible for the deformation and eastward extrusion of Tibetan plateau. The Indian plate movement also causes internal deformation which is evident from the infrequent occurrence of moderate earthquakes in the region.

Seismological waveform data have been used to delineate the deep seismic structure of the Indian shield, western Himalaya, Ladakh, Tibet, Arunachal Himalaya and eastern Himalaya syntaxis. For example, the Indian lithosphere is found to be only 90 $\mathrm{km}$ thick beneath the Shillong plateau deepening to $135 \mathrm{~km}$ on either side suggestive of a lithospheric upwarp related to the plateau uplift. The lithosphere thickens northward, with values reaching $\sim 180 \mathrm{~km}$ beneath the Eastern Himalaya. The trend of the LAB north of the foredeep region indicates that the Indian Plate plunges beneath the Eastern Himalaya. In the Garhwal Himalaya, the receiver function images show the Main Himalayan Thrust (MHT), the detachment at the base of the Himalayan thrust wedge, with a flat-ramp-flat geometry. The observed thickness of subducted Indian crust in Garhwal Himalaya is 20-28 $\mathrm{km}$.

In the eastern Himalayan syntaxis zone, the receiver function technique has been used to 
understand the crustal structure with $\sim 55 \mathrm{~km}$ thick crust as against the $\sim 70 \mathrm{~km}$ crust elsewhere in the Himalayan arc, and the GPS measurements provide evidence for oblique convergence at $20 \mathrm{~mm} /$ year.

After the 2001 Bhuj earthquake, a significant amount of work on the crustal structure, site amplification, attenuation, crustal deformation and seismogensis of the ongoing seismic activity has been done in the Kachchh region by the Institute of Seimological Research (ISR), Gandhinagar, Gujarat. Specifically, it is now revealed that the crustal and lithospheric thicknesses in the region are $35-42 \mathrm{~km}$ and $62-78 \mathrm{~km}$, respectively. The numerical block-andfault model of lithosphere dynamics and seismicity is used to understand crustal motion and seismicity in the Kachchh Rift Basin (KRB), Gujarat. The modeling suggests that an NNW-SSE trending compression is the principal driving force in the KRB which explains the basic features of the regional seismicity, direction of block motions, and the presence of an extensional stress regime associated with the Cambay rift zone.

Through examining the temporal changes in $b$ value and fractal dimension or $\mathrm{D}$ value of the seismicity associated with the 2001 Bhuj earthquake source region, it was observed that several episodes of abnormally low $\mathrm{b}$ and $\mathrm{D}$ values were associated with the occurrences of bursts of seismic activity in 2001, 2005, 2006, 2008, and 2010.

Seismological studies in the Indo-Gangetic plains suggest that the sedimentary thickness varies from 0.5 to $3.7 \mathrm{~km}$ with low velocity sediments having shearwave velocities in the range $0.72-2.5 \mathrm{~km} / \mathrm{s}$. Site amplification studies reveal a fundamental frequency of $0.13 \mathrm{~Hz}$; the amplification at this frequency varies between 20 and 60 . Calculations based on reasonable earthquake source, attenuation models and application of random vibration theory suggest that peak ground acceleration and peak ground velocity at soft sites near the Himalayan foothills located $100 \mathrm{~km}$ from the epicenter would be amplified by a factor of 2-4 and 6-12, respectively.

The 3-D shear velocity structure beneath south India's Dharwar Craton determined from fundamental mode Rayleigh-wave phase velocities reveals the existence of anomalously high velocity materials in the depth range of 50-100 km. Results suggest that intermediate composition for the crust beneath the
Eastern Dharwar Craton (EDC) is similar to those for other cratons. In contrast, the mid-Archaean exposed Western Dharwar Craton (WDC) crust has more mafic composition and exceptional thickness, a scenario at variance with the global observations. We interpret this thick mafic crust to represent undeformed geological segment of $3.36 \mathrm{Ga}$. The EDC with a nearly flat Moho, felsic to intermediate composition of crust and thin basal layer may represent regional delamination during the late-Archaean. The preserved distinct Moho topography across the Archaean terrains suggests it as compositional boundary. Considering the surface exposure of 15-20 $\mathrm{km}$ crust, based on P-T condition in the granulite segment of the WDC, it is speculated that a Himalayalike crustal thickness $(50-70 \mathrm{~km})$ beneath the middle Archaean crust exists which points towards a plate tectonic like scenario at $\sim 3.0 \mathrm{Ga}$.

The seismic Lithosphere Asthenosphere Boundary (LAB) or G discontinuity, a seismologically characterized abrupt drop in wave speed in the uppermost mantle, is one of the key issues in current geodynamics. Although plate tectonics started as a theory for the ocean, reports on LAB for normal oceanic regions are scarce due to paucity of seismic data, and whether or not the oceanic LAB grows with age is the key issue to be resolved. This study conducts a systematic survey for the oceanic LAB using S-to-p converted seismic waves along three margins of oceanic plates whose crustal age ranges from $\sim 10 \mathrm{Myr}$ to $\sim 130 \mathrm{Myr}$, to observe laterally continuous oceanic LAB images. The thickness of the oceanic plate estimated from LABs increases with the plate age, though scattered, suggesting that the evolution of oceanic lithosphere is predominantly governed by temperature and that the oceanic seismic LAB represents a boundary that grows with age.

Deciphering the seismic character of the young lithosphere near Mid-Oceanic Ridges (MORs) is a challenging endeavour. In this study the seismic structure of the oceanic plate near the MORs is determine using the $P$-to- $S$ conversions isolated from quality data recorded at five broadband seismological stations situated on ocean islands in their vicinity. Estimates of the crustal and lithospheric thickness values from waveform inversion of the $P$-receiver function stacks at individual stations reveal that the Moho depth varies between $\sim 10 \pm 1 \mathrm{~km}$ and $\sim 20 \pm$ 
$1 \mathrm{~km}$ with the depths of the LAB varying between $40 \pm 4$ and $\sim 65 \pm 7 \mathrm{~km}$. Evidence for an additional low-velocity layer is found below the expected LAB depths at stations on Ascension, São Jorge and Easter islands which probably relates to the presence of a hot spot corresponding to a magma chamber. Further, thinning of the upper mantle transition zone suggests a hotter mantle transition zone due to the possible presence of plumes in the mantle beneath the stations.

Singh et al. (2015) reviewed the variations in crustal and upper mantle structure beneath the Indian subcontinent with emphasis on passive seismic results supplemented by results of controlled seismic sources. Receiver function results from more than 600 seismic stations, and over 10,000 km of deep seismic profiles have been used to produce maps of average crustal velocities and thickness across the region. The crustal thickness varies from $29 \mathrm{~km}$ at the southern tip of India to $88 \mathrm{~km}$ under the Himalayan collision zone, and the patterns of variation show significant deviations from the predictions of global models. The average crustal shear velocity (Vs) is low in the Himalaya-Tibet collision zone compared to Indian shield. Major crustal features are as follows: (a) the Eastern Dharwar Craton has a thinner and simpler crustal structure crust than the Western Dharwar Craton, (b) Himalayan crustal thickness picks clearly follow a trend with elevation, (c) the rift zones of the Godavari graben and Narmada-Son Lineament show deeper depths of crust than their surroundings, and (d) most of the Indian cratonic fragments, Bundelkhand, Bhandara and Singhbhum, show thick crust in comparison to the Eastern Dharwar Craton. Heat flow and crustal thickness estimates do not show any positive correlations for India. Estimates of the thickness of the lithosphere show large inconsistencies among various techniques not only in terms of thickness but also in the nature of the transition to the asthenosphere (gradual or sharp). The lithosphere beneath India shows signs of attrition and preservation in different regions, with a highly heterogeneous nature, and does not appear to have been thinned on broader scale during India's rapid motion north towards Asia. The mantle transition zone beneath India is predominantly normal with some clear variations in the Himalayan region (early arrivals) and Southwest Deccan Volcanic Province and Southern Granulite Terrain (delayed arrivals). No clear patterns on influence on the mantle transition zone discontinuities can be associated with lithospheric thickness. Over 1000 anisotropic splitting parameters from SKS/ SKKS phases and 139 using direct $S$ waves are available from various studies. The shear-wave splitting results clearly show the dominance of absolute-plate-motion related strain of a highly anisotropic Indian lithospheric mantle with delay times between the split $\mathrm{S}$ phases close to $1 \mathrm{~s}$. There are still many parts of India where there is, at best, limited information on the character of the crust and the mantle beneath. It is to be hoped that further installations of permanent and temporary stations will fill these gaps and improve understanding of the geodynamic environment of the Indian subcontinent.

During the continental breakup of India from Africa in late Triassic (210 Ma) western India experienced crustal stretching (thinning) and formation of three failed rifts of Kachchh (also spelled as Kutch), Cambay and Narmada. The Kachchh rift is most active with potential of up to M8 earthquakes while Narmada rift has potential of up to M6.5 earthquakes and Camaby rift a potential of up to M6 earthquakes.

In the Kachchh rift (KR) magmatic intrusive were emplaced in the lower crust (may be starting in late Jurassic, $175 \mathrm{Ma}$ ). During the process several granitic intrusive rocks have come up to the surface all over Kachchh (Biswas, 2005). The xenoliths found in these intrusive might have originated in lower lithosphere and are dated $75 \mathrm{Ma}$ (Sen et al., 2009). The Deccan/Reunion mantle-plume during the end of Cretaceous caused lithosphere thinning and emplaced Deccan Volcanic flood basalt (Rastogi et al., 2014).

The Kachchh intraplate rift basin of western India and the intraplate region in or close to the Deccan Traps has been known to be active for centuries and many earthquakes have occurred in recent times: Koyna (Reservoir Induced Seismicity along with $\mathrm{M}_{\mathrm{w}}$ 6.3 in 1967 to $M_{w} 5.6$ in 2011) along the Kurdwadi rift, Latur (1993, $M_{w}$ 6.2), Jabalpur (1997, $M_{w}$ 5.8) and Bharuch (1970, $M_{w}$ 5.4) in the Narmada rift and Bhuj (2001, $M_{w}$ 7.7) in the Kachchh rift (KR). The 2001 Bhuj earthquake caused 14,000 deaths and destruction in a heavily populated and industrialized region. 


\section{Magnetotelluric Investigations}

Magetotelluric (MT) investigations in India are broadly grouped in two categories. First, given the sensitivity of electrical resistivity to fluid content, electrical resistivity imaging in seismic active zones are undertaken to broadly demarcate tectonic domains characterized by differing rheology and heterogeneity to gain an insight on the seismotectonics and seismogenesis of the earthquakes. In the second category, electrical resistivity images of crustal structures form the base to constrain crustal evolution models, thermal resource potential etc.

Close grid (1-3km spacing) 37 MT observations near Bhachau (epicenter of 2001 M7.7 Bhuj earthquake) indicate presence of south-dipping Kachchh Mainland fault and north-dipping South Wagad fault (Mohan et al., 2015).

MT measurements in the Garhwal Himalaya bring out an unambiguous evidence of a low angle north-east dipping intra-crustal high conducting layer (IC-HCL) with a well developed ramp at transition from the Lesser Himalaya to the Higher Himalaya. Attributing high conductivity of the layer to the metamorphic fluids, incorporation of the mechanical weakening effects of the fluids explain several facets of seismicity, e.g. clustering of large earthquakes on a linear plane defined by the top of the IC-HCL, later symbolizing brittle-ductile transition help to explain sharp cut-off depth of crustal seismicity; ramp symbolizing a block of low shear strength demarcates narrow belt of moderate magnitude high seismicity.

In the Sikkim Himalaya where strike slip becomes the dominating earthquake mechanism, magnetotelluric survey revealed a steep crustal-scale high resistivity structure with a step offset of $14 \mathrm{~km}$ at deep crustal depth, coinciding with the transition between MCTZ and Higher Himalaya. Another independent study relates this high resistivity 15-20 $\mathrm{km}$ thick block to the eclogitization of lower crust. The deflection of the arc normal slips by rigid eclogitized Indian crust in the depth range of 40-60 $\mathrm{km}$ is the primary source to generate strike-slip dominated large magnitude earthquakes.

Deep electrical images in three different tectonic scenarios, namely: Himalaya, Central Indian Tectonic zone and Southern Granulite terrain, bring out distinctive signature related to continent-continent collision, subduction-collision-accretion tectonics. The geoelectric sections across the Himalaya show near sub-vertical high conductivity structure of the Indus suture zone whereas beneath outer Himalaya, northward dipping signature of the anomalous conductive features at upper to mid-crustal depths are clearly mapped in agreement with the dominance of under thrusting. Such models give a clear evidence for the subduction and collision related dynamics. The profiles across the Central Indian tectonic zone constituting major east-west trending faults and mobile belts provided the evidence for the presence of mantle derived fluids at mid-crustal depths and also gave a clear evidence for the collision processes between the Bundelkhand craton and the Dharwar craton. The collision-accretion tectonic process is observed in Southern Granulite terrain of south India. Evidence for the exhumation of mantle derived fluids to the mid-crustal depths has been observed along the Vattalakundu-Kanyakumari profile, while the subduction-collision-accretion processes have been observed along Kolattur-Palani geotransect.

Synthesis of continuing MT surveys in the Deccan Volcanic Province (DVP) indicate that the thickness of the traps in DVP decreases from about $1.8 \mathrm{~km}$ in the west to a few hundred meters (approx. $400 \mathrm{~m}$ ) towards the east. The traps also exhibit considerable variation in resistivity, with higher resistivity (approx. 150-200 ohm-m) in the western half and lower resistivity (approx. 50-100 ohm-m) in the eastern half of DVP. Two significant fissure/ fracture zones have been detected in DVP, which might have acted as conduits for the outpouring of Deccan lavas in addition to the primary structures along the west coast and the Narmada-Son lineament (NSL) zones.

Exploiting the presence of resistive continental lower crust which serve as a window to resolve electrical conductivity structures of the mantle, it has been shown that the LAB beneath the Eastern Indian Craton is $95 \mathrm{~km}$, only half of the Slave craton. As cratonic signatures, depicted by ultrapotassic rocks from Gondwana coal fields, close to EIC, are preserved at least till early Cretaceous (117Ma), it is likely that Himlayan orogeny could have played a major role in delamination of the lithospheric roots of the EIC in addition to attendant seismicity. 
AMT has been carried out in the Bakreswar Hot Spring (BHS) area of eastern India to locate the geothermal source in the vicinity of BHS. The results show that the north-south fault close to Bakreswar is a shallow feature, not deeper than $300 \mathrm{~m}$, and thus cannot act as a heat source. The subsurface formation below the fault zone is highly resistive up to a great depth, indicating the absence of a heat source and geothermal reservoir in the vicinity of the BHS.

MT studies in hot spring areas of Chabsar (near Ahmedabad and close to western boundary of Camabay rift) and Tuwa (near Godhra in Proterozoic rocks $200 \mathrm{~km}$ east of Ahmedabad) indicate conducting zones and possible source of geothermal energy at depths of about $2.5 \mathrm{~km}$ (Mohan et al., 2015).

\section{Earthquake Hazard Studies}

\section{Seismic Zoning Map of India}

Seismic Zoning Map of India (Bureau of Indian Standards, 2000) divides India in zones II, III, IV and $\mathrm{V}$ having potential of earthquake intensities VI (M5), VII (M6), VIII (M7) and $\geq$ IX (Me $\geq 8)$, respectively. This map is prepared on the basis of intensities experienced at places and their tectonic belts. Andaman zone is assigned zone V. Himalayan belt is assigned zone V and IV. Kachchh is the only area outside Himalaya-Andaman belt which is assigned zone V. Koyna and Latur area is assigned zone IV. The Indo-Gangetic plains, Saurashtra peninsula, the west coast region and the Narmada belt is zone III. Most other parts of peninsular India are in zone II.

The national code assigns zone factors (pga) 0.1, 0.16, 0.24 and $0.36 \mathrm{~g}$ for zones II, III, IV and V, respectively which are multiplying factors to a response spectra to get spectral acceleration. Response spectra for soft soil, hard soil and rock were prepared a few decades back based on available strong motion for a few tens of worldwide earthquakes.

\section{Seismic Hazard Assessment}

Several agencies have prepared Probabilistic Seismic Hazard Assessment (PSHA) map of India. ISR has prepared such a map for Bureau of Indian Standards which will help all the citizens of India in adopting optimum seismic coefficients for earthquake resistant designing of buildings based on the probability of occurrence. The Seismic Zoning Map (SZ Map) of India currently recommended by BIS for designing earthquake resistant buildings is based on the magnitudes of the past earthquakes experienced in different tectonic (geological) zones. The logic used is what has happened at some zone can happen again. However, according to the seismic gap theory some seismologists believe that the areas which have not experienced earthquakes in the past in any tectonic belt may be more prone than the areas which have already experienced the earthquake. Hence the areas in Himalaya which are shown as zone 4 may have potential of zone 5. Moreover, the present SZ Map tells the potential of different zones without assigning any probability of occurrence. The assigned earthquake for a zone may occur tomorrow or after $10,000 \mathrm{yr}$ without giving any probability of occurrence. The Probabilistic Seismic Assessment (PSHA) Map gives the probability of occurrence in different time periods. Hence, the PSHA map is more practical. Also different types of structures need assessment for different return periods for assigning maximum possible earthquake in a tectonic zone. For example the ordinary buildings need only 475 years return period ( $10 \%$ probability in $50 \mathrm{yr}$, while an LNG terminal will need 2475 year return period ( $2 \%$ probability in $50 \mathrm{yr}$ ) and a Nuclear Power Plant will be designed for 10,000 years return period $(0.5 \%$ probability in 50 years). The PSHA map provides information towards this need. The PSHA map also provides fine gradation of hazard in a particular tectonic zone.

Parvez and Lyubushin (2010) generated seismic hazard map using Bayesian approach. Probabilistic seismic hazard maps were prepared: for Tamil Nadu by Menon et al. (2010), for NW Himalaya by Mahajan et al. (2010) and Yadav et al. (2011). Raghukanth and Das (2010) applied deterministic approach to assess seismic hazard scenario for Northeast India while Raghukanth $(2010 \mathrm{a}, \mathrm{b})$ for some other parts of India. An extensive study on peak ground motion predictions in India has been made for different rock sites by several researchers in diverse tectonic environ of India (Nath and Thingbaijam, 2011; Parvez et al., 2011). Rajendran et al. (2009) found that the historical seismicity corresponds with the present-day seismicity that can ascertain earthquake hazardous zone in the region. Srikanth et al. (2010) assessed earthquake vulnerability of existing buildings in Gandhidham and Adipur cities of Gujarat. 


\section{Seismic Microzonation}

Seismic Microzonation of different cities and areas provide knowledge for seismic safety factor to be considered for different heights of buildings. From this study, structural response curves are determined which give acceleration for different natural periods in $250-500 \mathrm{~m}$ grid. This analysis involves geotechnical investigations through numerous boreholes and geophysical measurements of seismic wave velocities by seismic survey and PS logging. Site characteristic maps are prepared for many areas based on Vs30, shear-wave velocity to $30 \mathrm{~m}$ depth measured by MASW shallow seismic and PS logging. Various geological units are assigned ranges of Vs30 values. GIS based shake maps are prepared. The liquefaction potential is also assessed. Effort has been made to standardize the procedure to be adopted by different organizations. Development of seismic microzonation of major urban centres has been recognized as a priority area and Ministry of Earth Sciences (MoES) has constituted a National Steering Committee.

Geological Survey of India has generated first order site response map for several important cities: Dehradun, Jammu, Ahmedabad, Jamnagar, Jalandhur, Bhavnagar, Bharuch, Agartala, Siliguri, Mumbai, Vizag, and Chenai, besides New Delhi, Jabalpur and Guwahati. Detailed seismic microzonation has been completed for the New Delhi and Kolkata cities by the National Centre for Seismology and IIT Kharagpur, respectively. Other academic and research institutions of India, such as IIT Kharagpur, IIT Roorkee, ISR, Gandhinagar, and NEIST, Jorhat are actively involved in conducting seismic Microzonation studies of Indian cities. First level seismic Microzonation has already been completed for Jabalpur, Sikkim, Guwahati, Bangalore, Ahmedabad, Dehradun, Chennai and Chandigarh. An important finding of ISR based on seismic Microzonation of several cities areas of Gujarat is that within $20 \mathrm{~km}$ from the faults with potential of M6 earthquake the low-rise buildings of 2-4 stories need to have $60-70 \%$ higher seismic factor than that recommended in the National Code. For the faults with potential of M8 earthquake the distance range is $30 \mathrm{~km}$ for low as well as high rise buildings.

\section{Public Outreach}

IMD, MoES, NDMA, NIDM, ISR and other agencies through their websites share different types of data sets, information about current earthquakes and catalogues of earthquakes in different states. These agencies allay unnecessary fear of people by explaining the possibilities of damage potential, how to live with that and phenomena like subterranean sounds generated by earthquakes. Builders, industrialists as well as academicians from institutes take regular help of these agencies. Training of engineers, masons, students and Govt. officers about earthquake safety and disaster management is imparted by NIDM, GIDM and various State Disaster Management Authorities like those of Bihar and UP. National code has been formed by Bureau of Indian Standards and periodically modified.

\section{Assessment of Tsunami Hazard and Alert System}

Indian coasts are vulnerable to tsunami hazards because of nearness to the tsunamigenic earthquake prone zones of Indonesia and Makran. India has taken effective steps in mitigating tsunami hazard by conducting a series of researches in the Indian Ocean by the Indian National Centre for Ocean Information Services (INCOIS). A state-of the-art tsunami warning system has been set up. The system comprises a network of seismic stations including international stations to compute earthquake parameters, simulated scenarios of travel time and run-up heights at 1800 coastal locations in the Indian Ocean, observing platforms for sea level variations, both in deep sea and coast, robust communication and dissemination system, data centre and decision support system.

\section{Earthquake Forecasting}

\section{Long-Term Assessment of Earthquake Potential across Different Faults:}

For the long-term assessment of earthquake potential along different faults several permanent and campaign mode GPS stations have been deployed in Himalaya and Kachchh which detect movements as small as 1$2 \mathrm{~mm} / \mathrm{yr}$. Vertical deformation is being monitored by InSAR study in collaboration with SAC-ISRO.

Rate of deformation in the past $2 \mathrm{Ma}$ is studied by active fault investigations in Himalaya and Kachchh. Dates of earthquakes in the past 20,000 yr are determined by paleoseismological and active fault investigations. Dating of sediments/prehistoric 
earthquakes is done in Optically Stimulated Luminescence Lab. Dates of pre-historic earthquakes give recurrence rates of large earthquakes in order to assess earthquake hazard along different geological faults. Active fault studies involve thorough examination of 3D satellite imageries, geological investigations supported by geophysical surveys like GPR, shallow seismic and resistivity imaging and finally observation of recent movements in trenches across faults.

\section{Medium- and Sort-term Precursors}

Research on medium and short-term earthquake forecasts is done by measuring several types of precursory phenomenon. ISR has established three Multiparametric Geophysical Observatories (MPGO) in Kachchh for earthquake prediction research. Eleven types of precursory parameters are being observed with Broadband Seismographs, GPS, magnetometers, ground water leveler, super conducting gravimeter, helium and radon detectors. WIHG has established MPGO at Ghuttu in Garhwal Himalaya while IIG at Shillong and Port Blair.

In a small and shallow earthquake zone assured of continuing small to moderate earthquakes with accompanying foreshocks like Koyna it appeared possible to forecast earthquakes. Nucleation method of short-term prediction was successfully applied to forecast $\mathrm{M} \sim 4-5$ Koyna earthquakes a week or two in advance (Rastogi and Mandal, 1999, Gupta et al., 2007)

\section{Significant Roles of some Important Agencies}

\section{Seismological Research at National Geophysical Research Institute (NGRI), Hyderabad}

NGRI is the premier research institute for seismological research. It maintains GPS networks and telemetered clusters of broadband seismographs in peninsular India and Koyna in addition to tens of stand- alone broadband seismographs at some regions including NE India and Andaman. Research is carried out on Physics of earthquakes and Earth's interior.

\section{Indian Institute of Technology, Roorkee (IITr)}

It has done pioneering work on earthquake engineering, strong motion and seismic hazard assessment of various project sites.

\section{Seismology at Geological Survey of India (GSI)}

GSI carries out intensity survey for damaging earthquakes and first order site response study of different cities and areas. It maintains broadband seismograph stations at Nagpur since 1995 and at Jabalpur since 1997. Since 2015 BB, GPS and SM instruments are operated at Mangan (Sikkim), Agartala (Tripura), Itanagar (Arunachal), Nagpur and Jammu.

\section{Seismological Studies by Institute of Seismological Research (ISR)}

ISR is involved in earthquake monitoring in the Gujarat state. Earthquake information is processed within minutes with the help of 60 VSAT-connected seismic stations and auto-location. Now earthquake early warning system is being set-up.

ISR estimates seismic hazard for Nuclear Power plants, LNG storage terminals, petrochemical plants, different types of industrial sites, tall structures, ports etc. Seismic hazard maps of Gujarat in respect of peak ground acceleration, spectral acceleration for different natural periods of buildings, amplified frequencies and amplification have been prepared. Seismic Microzonation vulnerability assessment have been done for several cities.

ISR has done active-fault study in Kachchh, Gujarat and found faults of Kachchh Mainland, Allah Bund, Island Belt, Bela and South Wagad to be active. GPS and InSAR (Interferometric Synthetic Aperture Radar) studies have measured deformation along active fault lines. New seismic surveys are being done to know details of some major faults in Kachchh. Mobile arrays of additional 50 seismographs are being deployed to know details of other smaller but active faults.

Seismological Studies by CSIR, Northeast Inst. Sc. \& Tech. (NEIST) Jorhat

The Northeast India region is one of the most active zones in the world; the region is jawed between the two arcs, the Himalayan arc to the north and the IndoBurmese arc to the east. The region bounded by latitude $22-29^{\circ} \mathrm{N}$ and longitude $90-98^{\circ} \mathrm{E}$, produced two great earthquakes $(M>8.0)$ and about 20 large earthquakes $(7.0>\mathrm{M}>8.0)$ since 1897 . The Shillong Plateau was the source area for the 1897 great 
earthquake M 8.7, and the Assam Syntaxis zone for the 1950 great earthquake M 8.6. Several large earthquakes occurred along the Indo-Burma ranges. CSIR NEIST-Jorhat carries out research on earthquake seismology based on the data of standalone seismographs since 1982. VSAT connected seismic network is working since 2006. Strong Motion accelerographs and GPS stations are being added.

A new updated catalogue has been prepared for NE India with more local and lower magnitude earthquakes. Earthquake source inversion and highfrequency rupture imaging has been done for some earthquakes of Northeast India. Fractal analysis in Northeast India has been tried. The Studies include 3D travel time tomography, waveform tomography, surface wave inversion, joint inversion, stress inversion. Strain rate is being measured in Northeast India using campaign mode GPS measurements. Crustal imaging using multiple geophysical observations is being carried out.

Probabilistic seismic hazard has been assessed for Guwahati and Shillong which are two most populous cities of Northeast India. Site effects on strong ground motions for these two cities have been worked out by investigating sub-surface soil layering which affect the amplitude, frequency and duration of ground motion through mechanisms of ground response (including impedance and resonance effects). Empirical relations are proposed for the ground motion parameters as a function of earthquake magnitude, distance, fault type, source depth and velocity characteristics of medium. Seismotectonics of the study region is examined and a maximum credible earthquake Ms 8.0 is presumed from the Brahmaputra fault, the nearest source zone in the city area. Such great/major event may cause intensity of 9 or more with a probability of 0.95 in the Guwahati city during time interval of 500 years. Further, the design spectrum with $67 \%$ confidence level is constructed. High resolution satellite data is being used for urban land cover classification in terms of spatial distribution of different types of buildings, the carrying capacity of the street network or the identification of open spaces of Shillong. DEM (Digital Elevation Model) has been prepared to study landslide hazard.

Active fault study is being carried out in the junction area of northwest trending lithotectonic units of the Mishmi block and the almost N-S trending eastern Himalayan lithotectonic units along the Siang fracture. A large window in the Siang river section exposes Paleocene rocks interbeded with Abhor volcanic as the subthrust package and MBT as the roof thrust. Active faulting along the Himalayan Front is observed. Left-lateral strike slip faults displacing Mishmi Thrust Zone had been observed. Morphological and sedimentary records at Siang, Dibang and Lohit rivers at Pasighat, Dambuk, Roing, Tezu and Parsuramkund areas in the NE Himalaya were studied with the help of terraces, for the evidences of the climate-tectonic interplay. Drainage maps were prepared and structurally controlled drainages were observed in the study area. Mishmi Thrust zone is found to be tectonically active with the uplifting of the Quaternary fluvial sediments for a height of about $40 \mathrm{~m}$ from the present day river channel.

Tectonic stress regime in the Shillong plateau, northeast region of India, is examined by stress tensor inversion of some 97 reliable fault plane solutions. The stress regime varies from western part to eastern part of the plateau. The eastern part of the plateau is dominated by NNE-SSW compression and the western part by NNW-SSE compression. The NNWSSE compression in the western part may be due to the tectonic loading induced by the Himalayan orogeny in the north, and the NNE-SSW compression in the eastern part may be attributed to the inûuence of oblique convergence of the Indian plate beneath the Indo-Burma ranges. Further, Gravitational Potential Energy (GPE) derived stress also indicates a variation from west to east.

\section{Significant Future Plans}

\section{Earthquake Early Warning System}

Earthquake Early Warning Systems are being installed in Garhwal Himalaya (100 accelerographs in $250 \mathrm{~km}$ $\mathrm{x} 100 \mathrm{~km}$ area) by IITr and in Kutch (50 accelerogrphs in $75 \mathrm{~km} \times 100 \mathrm{~km}$ area) by ISR. Deployment of instruments will be completed soon, software has been installed and the issue of data transmission from remote sites to the central recording site is being addressed. Information about magnitude and location of earthquake will be processed in seconds and will enable about 20-40 s early warning at distances of 200 to $300 \mathrm{~km}$. 


\section{Shake Maps}

MoES is providing shake maps soon after significant earthquakes. The GIS based intelligent earthquake hazard maps will be soon available in website which are useful for planning developmental activities. Anyone can log-in and see how much damage can be in an area for different magnitudes in any region and what kind of safety factors are to be considered in a particular area. GIS base Shake maps will be put soon after any earthquake so that the Government and NGOs can plan rescue without delay of precious time in which a number of lives can be saved. It is an important issue as break down in communications invariably happens after the earthquakes.

\section{Concluding Remarks}

More than $50 \%$ of Indian landmass has severe earthquake hazard and hazard is increasing due to shoddy constructions and increasing population. With fast developing infrastructure and industrial

\section{References}

Acton C E, Priestley K, Mitra S and Gaur V K (2011) Crustal structure of the Darjeeling-Sikkim Himalaya and Southern Tibet Geophys Jour Int 184 829-852 doi: 10.1111/ j.1365246X.2010.04868.x

Ader T, Avouac J P, Liu-Zeng J, Lyon-Caen H, Bollinger L, Galetzka J, Genrich J, Thomas M, Chanard K, Sapkota S M, Rajaure S, Shrestha P, Ding L and Flouzat M (2012) Convergence rate across the Nepal Himalaya and Interseismic coupling on the Main Himalayan Thrust: Implications for seismic hazard J Geophys Res 117 B0440310

Ambikapathy A and Gahalaut V K (2011) Time clustering of earthquakes in the Sumatra and Himalayan region Current Science 100 1068-1071

Anbazhagan P, Thingbaijam K K S, Nath S K, Kumaran J N and Sitharam T G (2010) Multi-Criteria Seismic Hazard Evaluation for Bangalore City, India Jour Asian Earth Sci 38 186-198

Andrade V and Rajendran K (2011) Intraplate response to the great 2004 Sumatra-Andaman earthquake: A study from the Andaman segment Bull Seismol Soc Amer 101 506-514 doi: 10.1785/0120100155

Arora B R, Gahalaut V K and Kumar Naresh (2012) Structural control on along-strike variation in the seismicity of the development, various agencies like IMD, ISR, IITkhg and IISc are carrying out earthquake hazard studies and microzonation. It is evident that significant progress has been made to understand the crustal structure, crustal deformation, seismogenesis using various seismological and geophysical methods, The monitoring networks, particularly the seismological and geodetic networks, have been strengthened. Efforts have been made towards mitigating the seismic hazard by taking up seismic microzonation of several cities. Some progress has been made towards deployment of earthquake early warning. It is important that such efforts continue through funding of new projects, particularly dealing with consolidating the observational data base and basic seismological research.

\section{Acknowledgelment}

Author is thankful to VK Gahalaut for reviewing the manuscript and providing information about the studies carried out through the MoES.

northwest Himalaya $J$ Asian Earth Sci 57 15-24 DOI: 10.1016/j.jseaes.(2012).06.001

Banerjee P and Burgmann R (2002) Convergence across the northwest Himalaya from GPS measurements. Geophysical Research Letters 291652 doi:10.1029/ 2002GL015184

Banerjee P, Burgmann R, Nagarajan B and Apel E (2008) Intraplate deformation of the Indian subcontinent Geophysical Research Letters 35 L18301 doi:10.1029/2008GL035468

Bansal A R and Ogata Y (2013) A non-stationary epidemic type aftershock sequence model for seismicity prior to the December 26, 2004 M 9.1 Sumatra-Andaman Islands megaearthquake Solid Earth 118 616-629 DOI: 10.1002/ jgrb.50068

Bansal A R, Dimri V P and Babu K K (2013) Epidemic type aftershock sequence (ETAS) modeling of northeastern Himalayan seismicity J Seism 17 255-264

Bansal B K (2011) "Preface", on Seismic Microzonation Handbook, Geoscience Division, Ministry of Earth Sciences, Government of India, 518

Bapanayya C, Raju P A, Das Sharma S and Ramesh D S (2011) Information theory-based measures of similarity for imaging shallow-mantle discontinuities. Lithosphere J Geol Soc Am 3 289-303 Doi:10.1130/L152.1

Barman P, Ray J D, Kumar A, Chowdhury J D and Mahanta K 
(2014) Estimation of present-day interseismic deformation in Kopili fault zone of north-east India using GPS measurements Geomatics Nat Haz Risk, doi.org/10.1080/ 19475705.(2014).983187

Baruah, Santanu, Baruah Saurabh, Kalita A and Kayal J R (2011) Ground Motion Parameters in Shillong \& Mikir Plateau of Northeastern India Geomaics Nat Haz Risk doi: 10.1080/ 19475705.(2011).568070

Baruah, Santanu, Baruah, Saurabh and Kayal J R (2013) State of Tectonic Stress in Northeast India and Adjoining South Asia Region: An Appraisal Bull Seism Soc Am 103 894910 doi: 10.1785/01(2011)0354

Baruah, Santanu, Baruah, Saurabh, Bora P K, Duarah R, Kalita A, Biswas R, Gogoi N and Kayal J R (2012) Moment Magnitude (MW) and Local Magnitude (ML) Relationship for Earthquakes in Northeast India Pure and Appl Geophys DOI: $10.1007 / \mathrm{s} 00024-012-0465-9$

Bhattacharya P M and Kayal J R (2007) Application of fractal in marine services, Study of the Sumatra 2004 Earthquake (Mw 9.3) sequence in Andaman Nicobar Islands Ind Jour Marine Sci 36 136-140

Bhattacharya P M, Kayal J R, Barua S and Arfeiev S S (2010) Earthquake source zones in NE India, Seismic tomography and fractal dimension mapping, PAGEOPH, doi: 10.1007/ S00024-010-9984-2

Bhattacharya P M, Mukhopadhya S, Majumdar R K and Kayal J R (2008) 3-D Seismic structure of the N-E India region and its implications for local and regional tectonics Jour Asian Earth Seismological Research in India 367 Sci 33 25-41

Bilham R, Larson K and Freymueller J (1997) GPS measurements of present-day convergence across the Nepal Himalaya Nature 386 61-64

Biswas S K (2005) A Review of Structure and Tectonics of Kutch Basin, Western India, with special reference to Earthquakes Current Science $\mathbf{8 8} 15$

Caldwell W B, Klemperer S L, Lawrence J F and Rai S S (2013) Characterizing the Main Himalayan Thrust in the Garhwal Himalaya, India with receiver function CCP stacking Earth Planet Sci Lett 367 15-27

Caldwell W B, Klemperer S L, Rai S S and Lawrence J F (2009) Partial melt in the upper-middle crust of the northwest Himalaya revealed by Rayleigh wave dispersion Tectonophysics 477 58-65

Catherine J K, Gahalaut V K, Srinivas N, Kumar S and Nagarajan B (2014) Evidence of Strain Accumulation in the Andaman Region for the Giant 2004 Sumatra Andaman Earthquake Bull Seism Soc Am 104 587-591
Chopra S, Kumar D and Rastogi B K (2010) Estimation of strong Ground motion for the $2001 \mathrm{Bhuj}$ (Mw .6), India earthquake Pageoph 167 1317-1330

Chopra S, Kumar D and Rastogi B K (2011) Attenuation of high frequency $\mathrm{P}$ and $\mathrm{S}$ waves in the Gujarat Region, India Pageoph 168 797-813

Chopra S, Yadav R B S, Patel H, Kumar S, Rao K M, Rastogi B K, Hameed A and Srivastava S (2008) The Gujarat (India) Seismic Network Seismol Res Letts 79 806-815

Chowdhuri S N, Singh O P and Majumdar R K (2011) Site Response studies in Agartala Urban agglomeration Natural Hazards 59 329-345

Chowdhuri S N, Singh O P, Mishra O P and Kayal J R (2008) Microzonation study from ambient noise measurement for assessing site effects in Krishnagar area and its significance with the damage pattern of Ms 4.3 of the 24th September, 1996 earthquake Spl Issue Indian Minerals 61 183-192

Das R and Wason H R (2010) Comment on "A Homogenous and Complete Earthquake Catalog for Northeast India and the Adjoining Region" by R B S Yadav, P Bormann, B K Rastogi, M C Das and S Chopra Seismol Res Lettrs 81 $235-240$

Das Sharma S and Ramesh D S (2013) Imaging mantle lithosphere for diamond prospecting in southeast India Lithosphere $\mathbf{5}$ $331-342$

Dasgupta S, Mukhopadhyay B and Acharyya A (2008) Seismotectonics of the Andaman-Nicobar Region: Constraints from Aftershocks within 24 Hours of the Great 26 December 2004 Earthquake, In: Sumatra-Andaman earthquake and Tsunami 26 December 2004 (Ed. Sujit Dasgupta) Geol Sur India Spl Pub 89 95-104

Dasgupta S, Mukhopadhyay B and Bhattacharya A (2007) Seismicity Pattern in north Sumatra- Great Nicobar Region: In Search of Precursor for the 26 December 2004 Earthquake Jour Earth Syst Sci 116 215-223 DOI: 10.1007/ s11069-010-9557-y

Dasgupta S, Mukhopadhyay B and Mukhopadhyay M (2010) Next Impending Earthquake in Northern Burmese Arc Search for A Probable Precursor, Mem 75 Geol Soc Ind $69-80$

Devi E U, Kumar P and Kumar M R (2011) Imaging the Indian lithosphere beneath the eastern Himalayan region Geophys J Int 187 631-641

Dutta P, Naskara M and Mishra O P (2011) South Asia Earthquake Catalogue magnitude data regression analyses Int Jour Statist and Analys 1 161-170

Gahalaut V K and Arora B R (2012) Segmentation of seismicity 
along the Himalayan Arc due to structural heterogeneities in the under-thrusting Indian plate and overriding Himalayan wedge Episodes 35 493-500

Gahalaut V K and Bhaskar Kundu (2012) Possible influence of subducting ridges on the Himalayan arc and on the ruptures of great and major Himalayan earthquakes Gond Res $\mathbf{2 1}$ 1080-1088 doi: 10.1016/j.gr.(2011).07.021

Gahalaut V K, Shikha Rajput and Kundu B (2011) Low seismicity in the Bhutan Himalaya and the stress shadow of the 1897 Shillong Plateau earthquake Phys Earth Planet Int 186 97102 doi: 10.1016/j.pepi.(2011).04.009

Gahalaut, Kalpana and Hassoup A (2012) Role of fluids in the earthquake occurrence around Aswan reservoir Egypt $J$ Geophy Res 117 B02303 doi: 1029/(2011)JB008796

Gahalaut, Vineet K, Kundu, Bhaskar, Laishram, Sunil Singh et al (2013) Aseismic plate boundary in the Indo-Burmese wedge, northwest Sunda Arc Geology 41 235-238 DOI: 10.1130/ G33771.1

Gavrilenko P, Singh C and Chadha R K (2010) Modelling the hydromechanical response in the neighborhood of Koyna reservoir (India): Results of the initial filling period Geophys Jour Int 183 461-477

Ghosal A, Ghosh, Uma and Kayal J R (2012) A detailed b-value and fractal dimension study of the March 1999 Chamoli earthquake (M s 6.6) aftershock sequence in western Himalaya Geomatics Nat Haz Risk doi: 10.1080/19475705. (2011).627380

Ghosh D and Mishra O P (2008a) Earthquake-generating Process in Pakistan-Kashmir Himalayan Front: A Tectonic Overview Sp Issue Indian Minerals 61 27-40

Ghosh D and Mishra O P (2008b) The 2004 Sumatra-Andaman Earthquake Sequence and its Implications for Seismic Coupling: Future Vulnerability Spl Issue Indian Minerals 61 93-112

Ghosh D and Mishra O P (2008c) Possible Causes of 12 May 2008, Wenchuan Earthquake at Longmen Shan Collision Front, Western Sichuan Province, Central China Spl Issue Indian Minerals 61 213-222

Gupta H and Gahalaut V K (2014) Seismotectonics and large earthquake generation in the Himalayan region Gond Res 25 204-213

Gupta H K (2007) Earthquake forecast appears feasible at Koyna, India Curr Sci 93 843-848

Gupta H K (2008) India's Initiative in Mitigating Tsunami and Storm Surge Hazard Jour Earthq Tsunami 2 287-295

Gupta H K (2008) Two Significant Developments in Seismology in India: Study of Artificial Water Reservoir Triggered
Earthquakes and Tsunami Hazard Mitigation, Mem. 68, Golden Jubilee Volume of Geol Soc India 15-30

Gupta H K (2009) India's Initiative in Mitigating Tsunami and Storm Surge Hazard Jour of Earthq and Tsunami 5 1-9

Gupta H K (2010) Co-operation Plan on Hazards \& Disaster Risk Reduction in Asia and Pacific, Geophysical Hazards, Tom Beer (Ed), IYPE, Springer, 83-101

Gupta H K, Rao N P, Shashidhar D and Mallika K (2008) The Disastrous M 7.9 Sichuan Earthquake of 12 May 2008 Jour Geol Soc Ind 72 325-330

Gupta Harsh, Shashidhar D, Periera M, Rao N P, Nagesh D, Satyanarayana H V S, Satish Saha R T, Babu Naik and Dimri V P (2007) Short Term Forecast for an M 4 earthquake at Koyna, India J Geol Soc In 701091

Gupta S, Zhao D and Rai S S (2009) Seismic imaging of the upper mantle under the Erebus hotspot in Antarctica Gondwana Res 16 109-118

Haggag H M, Bhattacharya P M, Kamal S and Kayal J R (2009) Seismicity and 3-D velocity structure in Aswan reservoir lake area, Egypt Tectonophysics 476 450-459

Haldar C, Kumar P and Kumar M R (2014) Seismic structure of the lithosphere and upper mantle beneath the ocean islands near mid-oceanic ridges Solid Earth 5 327-337

Hazarika P, Kumar M R and Kumar D (2013) Attenuation character of seismic waves in Sikkim Himalay Geophy $J$ Int 195 544-557

Imtiyaz A P, Sutar A K, Mridula M, Mishra S K and Rai S S (2008) Estimation of Coda Attenuation in the Andaman Islands using Local Earthquakes, Presented in the 7th Gen Assemb Asian Seismol Comm Tsukuba, Japan, November 24-27

Imtiyaz A P, Mridula M and Rai S S (2007) Coda Q estimates in the Andaman Region using Local Earthquakes, Presented in XXIV General Assembly of the International Union of Geodesy and Geophysics (IUGG-2007) meeting held at Perugia, Italy held during July 2-13

ISR (2009) Institute of Seismological Research Report, www.isr.gujarat.gov.in

Jade S (2004) Estimates of plate velocity and crustal deformation in the Indian subcontinent using GPS geodesy Current Science 86 1443-1448

Jade S, Bhatt B C, Yang Z, Bendick R, Gaur V K, Molnar P, Anand M B and Kumar D (2004) Preliminary tests of plate-like or continuous deformation in Tibet Geological Society of America Bulletin 116 1385-1391

Jade S, Mukul M, Gaur V K, Kumar K, Shrungeshwar T S, Satyal G S, Dumka G S, Jagannathan S, Ananada M B, 
Kumar P D and Banerjee S (2014) Contemporary deformation in the Kashmir-Himachal, Garhwal and Kumaon Himalaya: significant insights from 1995-2008 GPS time series J Geodesy 88 539-557

Jaiswal R K, Singh A P, Rastogi B K and Murty T S (2011) Aftershock Sequences of two Great Sumatra Earthquakes of 2004 and 2005 and Simulation of the Minor Tsunami Generated on September 12, 2007 in the Indian Ocean and Its Effect on Indian Coast Natural Hazards 57 7-26 DOI: 10.1007/s11069-010-9637-z

Kayal J R, Arefiev S S, Saurabh, Baruah, Hazarika D, Gogoi N, Gautam J L, Santanu Baruah, Dorbath C and Tatevossian R (2012) Large and great earthquakes in the Shillong plateau-Assam valley area of Northeast India Region: Popup and transverse tectonics Tectonophysics 532-535 (2012) 186-192

Kayal J R, Das Vishal and Ghosh Uma (2012) An Appraisal of the 2001 Bhuj earthquake ( $\mathrm{Mw}$ 7.7) tectonic model in SCR India: Fractal dimension and b-value mapping, Pure and Appl Geophys doi: 10.1007/s00024-012-0503-7

Kayal J R, Srivastava V K, Chatterjee R and Khan P K (2011) Evaluation of crustal and upper mantle structures using receiver function analysis: ISM broadband observatory data Jour Geol Soc Ind 78 76-80

Kayane H, Ikeda Y, Echigo T, Shishikura N, Kamataki T, Satake K, Mullick J N, Basir S R, Chakrabortty G K and Ghosh Roy A K (2007) Coseismic and post seismic creep in the Andaman Islands associated with the 2004 Sumatra earthquake Geophys Res Letts $\mathbf{3 4}$

Khan P K (2011) Role of unbalanced slab resistive force in the 2004 off Sumatra mega-earthquake (Mw > 9.0) event Int Jour Earth Sci 100 1749-1758 DOI: 10.1007/s00531-0100576-4

Khan P K, Biswas B, Samdarshi P and Prasad R (2011b) Seismicity and the Coda-Q Variation in Eastern Indian Shield Region Ind Jour Geosci 65 131-138

Khan P K, Ghosh M, Chakraborty P P and Mukherjee D (2011a) Seismic b-value and the assessment of ambient stress in Northeast India, PAGEOPH 168 1693-1706 DOI: 10.1007/s00024-010-0194-x

Khan P K, Mohanty S and Mohanty M (2010b) Geodynamic implications for the 8 October 2005 North Pakistan earthquake Surveys Geophys DOI: 10.1007/s10712-0099083-1

Khan P K, Mukherjee G and Chakraborty P P (2010a) Seismotectonic overview of the Burma-Andaman-Sumatra subduction margin preceding the 2004 off Sumatra megaevent Mem 75 Jour Geol Soc Ind 81-95
Kumar M R and Singh A (2010) Seismic anisotropy of the Indian tectonic plate: Deciphering continental scale mantle deformation patterns Curr Sci 99 1751-1761

Kumar M R, Mishra D C and Singh B (2013) Lithosphere, crust and basement ridges across Ganga and Indus basins and seismicity along the Himalayan front, India and Western Fold Belt Pakistan J Asian Earth Sci 75 126-140

Kumar M Ravi, Saikia Dipankar, Singh Arun et al. (2013) Low shear velocities in the sub-lithospheric mantle beneath the Indian shield Solid Earth 118 1142-1155 DOI: 10.1002 / jgrb.50114

Kumar N Mate S and Mukhopadhyay S (2014) Estimation of Qp and Qs of Kinnaur Himalaya J Seismology 18 47-59 DOI: 10.1007/s10950-013-9399-7

Kumar N, Arora B R, Mukhopadhyay S and Yadav D K (2013) Seismogenesis of Clustered Seismicity beneath the KangraChamba Sector of Northwest Himalaya: Constraints from 3D Local Earthquake Tomography J Asian Earth Sc 62 638-646

Kumar N, Kumar M R, Singh A, Raju P S and Rao N P (2010b) Shear wave anisotropy of the Godavari rift in the south Indian shield: Rift signature or APM related strain? Phys Earth Planet Inters doi:10.1016/j/pepi.2

Kumar N, Sharma J, Arora B R. and Mukhopadhyay S (2009) Seismotectonic model of the Kangra-Chamba sector of NW Himalaya: Constraints from joint hypocenter determination and focal mechanism Bull Seism Soc Amer 99 doi: 10.17850120080220

Kumar P and Kawakatsu H (2011) Imaging the seismic lithosphere-asthenosphere boundary of the oceanic plate Geochem Geophys Geosys (G3) 12 Q01006, doi: 10.1029/ 2010 GC 003358

Kumar Prakash H, Kawakatsu M, Shinohara T, Kanazawa Araki E and Kiyoshi S (2011) P and S receiver function analysis of seafloor borehole broadband seismic data J Geophys Res 116 B12308 doi:10.1029/ (2011)JB008506

Kumar Prakash, Kumar M R, Srijayanthi G, Arora K, Srinagesh D, Chadha R K and Sen M K (2013) Imaging the lithosphere-asthenosphere boundary of the Indian plate using converted wave techniques Solid Earth 118 53075319

Kumar S, Wesnousky S G, Jayangondaperumal R, Nakata T, Kumahara Y and Singh V (2010a) Paleoseismological evidence of surface faulting along the northeastern Himalayan front, India: Timing, size, and spatial extent of great earthquakes Jour Geophys Res 115 B12422 doi: 10.1029/2009JB006789

Kumar T, Vijay, Jagadeesh S and Rai S S (2012) Crustal structure 
beneath the Archean-Proterozoic terrain north India from receiver function modelling J Asian Earth Sci 58 108-118 DOI: 10.1016/j.jseaes.(2012).06.015

Kumar, Prakash, Kind Rainer and Yuan Xiaohui et al. (2012) US Array Receiver Function Images of the LithosphereAsthenosphere Boundary Seism Res Lett 83 486-491 DOI: 10.1785/gssrl.83.3.486

Kundu B and Gahalaut V K (2011) Slab detachment on Subducted Indo-Australian plate beneath Sunda arc, Indonesia J Earth Sys Sci 120 193-204

Kundu B and Gahalaut V K (2012) Earthquake occurrence processes in the Indo-Burmese wedge and Sagaing fault region Tectonophysics 524-525 135-146

Kundu B, Legrand D, Gahalaut K, Gahalaut V K, Mahesh P, Kamesh Raju K A, Catherine J K, Ambikapthy A and Chadha R K (2012) The 2005 volcano-tectonic earthquake swarm in the Andaman Sea: Triggered by the 2004 great Sumatra-Andaman earthquake Tectonics 31 TC5009 doi: 10.1029/(2012)TC003138

Lyubushin AA, Arora B R and Kumar N (2010) Investigation of seismicity in western Himalaya Russ Jour Geophys Res 11 27-34

Mahajan A K, Thakur V C, Sharma M L and Chauhan M (2010) Probabilistic seismic hazard map of NW Himalaya and its adjoining area, India Natural Hazards 53 443-457

Mahesh P, Gahalaut V K and Catherine J K et al. (2012) Localized crustal deformation in the Godavari failed rift, India Earth Planet Sci Lett 333 46-51 doi: 10.1016/j.epsl.(2012).04.008

Mahesh P, Gupta Sandeep and Rai S S et al. (2012) Fluid driven earthquakes in the Chamoli Region, Garhwal Himalaya: evidence from local earthquake tomography Geophy J Int 191 1295-1304 doi: 10.1111/j.1365-246X.(2012).05672

Mallika K, Gupta Harsh and Shashidhar D et al. (2013) Temporal variation of $b$ value associated with $M$ similar to 4 earthquakes in the reservoir-triggered seismic environment of the Koyna-Warna region, Western India J Seism 17 189195 doi: 10.1007/s10950-012-9318-3

Mandal P (2007) Sediment thicknesses and Qs vs. Qp relations in the Kachchh Rift Basin, Gujarat, India using Sp converted phases, PAGEOPH, 164 p. 135-160

Mandal P and Chadha R K (2008) Three-dimensional velocity imaging of the Kachchh seismic zone, Gujarat, India Tectonophysics $\mathbf{4 5 2}$ 1-16

Mandal Prantik (2011) Passive-Source Seismic Imaging of the Crust and Upper Mantle beneath the 2001 Mw 7.7 Bhuj Earthquake Region, Gujarat, India Bull Seism Soc Am 102 252-266 doi: 10.1785/01(2011)0116
Mandal Prantik (2011) Upper mantle seismic anisotropy in the intra-continental Kachchh rift zone, Gujarat, India Tectonophysic 509 81-92 doi: 10.1016/J.Tecto.(2011). 05.013

Mandal Prantik (2013) Seismogenesis of the uninterrupted occurrence of the aftershock activity in the 2001 Bhuj earthquake zone, Gujarat, India, during 2001-2010 Nat Haz 65 1063-1083 doi: 10.1007/s11069-012-0115-7

Mandal Prantik, Pandey O P (2011) Seismogenesis of the lower crustal intraplate earthquakes occurring in Kachchh, Gujarat, India J Asian Earth Sci 42 479-491 Doi: 10.1016/ J.Jseaes.(2011).05.005

Mandal Prantik, Rodkin and Mikhail V (2011) Seismic imaging of the 2001 Bhuj Mw7.7 earthquake source zone: b-value, fractal dimension and seismic velocity tomography studies Tectonophysics 512 1-11 doi: 10.1016/J.Tecto.(2011). 09.004

Md. Shofiqul Islam, Ryuichi Shinjo and Kayal J R (2011) Popup tectonics in Shillong plateau in northeast India: Insight from numerical simulations Gond Res 20 395-404

Menon A, Ornthammarath T, Corigliano M and Lai C G (2010) Probabilistic Seismic Hazard Macrozonation of Tamil Nadu in Southern India Bull Seismol Soc Amer 100 1320-1341 doi: 10.1785/0120090071

Mishra D C, Ravi Kumar M and Arora K (2012) Buoyant lithosphere and asthenosphere under Tibet and Indian plate constrained from gravity and geoid lows and seismotectonics of deep focus earthquakes of HinduKush and Burmese arc J Asian Earth Sci 48 93-110

Mishra O P (2011) Three-dimensional tomography of Northeast India and Indo-Burma region and its implications for Earthquake risks. In National Workshop on Earthquake Risk Mitigation: Strategy in Northeast, 40-54

Mishra O P, Kayal J R, Chakrabortty G K, Singh O P and Ghosh D (2007a) Aftershocks investigation in Andaman-Nicobar islands of India and its seismotectonic implications Bull Seism Soc Amer 97 S71-S85

Mishra O P, Singh O P, Chakrabortty G K and Kayal J R (2007b) Aftershock investigation in Andaman-Nicobar Islands: An antidote to public panic Seismol Res Letts 78 591-600

Mishra O P, Singh O P, Marathe S, Pathak R C, Singh S K, Mishra H P, Saha D K, Ghosh B, Chakrabortty G K, Mukherjee K K and Ram S (2009) A preliminary note on the recent (Late 2009) earthquakes around Koyna in Maharashtra and their seismogenesis Ind Jour Geosci 63 333-339

Mishra O P, Zhao D and Wang Z (2008) The Genesis of the 2001 Bhuj, India Earthquake (Mw 7.6): A Puzzle for Peninsular 
India? Specl Issue Indian Minerals 61 149-170

Mishra O P, Zhao D, Ghosh C, Wang Z, Singh O P, Ghosh B, Mukherjee K K, Saha D K, Chakrabortty G K and Gaonkar S G (2010) Role of crustal heterogeneity beneath AndamanNicobar Islands and its implications for coastal hazards Natural Hazards doi: 10.1007/s11069-010-9678-3

Mitra S, Bhattacharya S N and Nath S K (2008) Crustal Structure of the Western Bengal Basin from joint analysis of Teleseismic Receiver Functions and Rayleigh wave dispersion Bull Seismol Soc Amer 98 2715-2723

Mitra S, Kainkaryam S M, Padhi A, Rai S S and Bhattacharya S N (2011) The Himalayan foreland basin crust and upper mantle Phys Earth Planet Inters 184 34-40

Mitra S, Priestley K, Acton C and Gaur V K (2011) Anomalous surface wave dispersion and the enigma of "continentallike" structure for the Bay of Bengal Jour Asian Earth Sci doi: 10.1016/j.jseaes.2011.07.008

MoES (2011a) Ministry of Earth Sciences Draft Approach Paper for the12th five year plan (2012-2017), http://dod.nic.in

MoES (2011b) Seismic Microzonation Handbook, Geoscience Division, Ministry of Earth Sciences, Government of India, 518

Mohan G, Kumar M R, Saikia D, Kumar K A P, Tiwari P K and Surve $G$ (2012) Imprints of volcanism in the upper mantle beneath the NW Deccan volcanic province Lithosphere 4 150-159 doi: 10.1130/L178.1

Mohan, Kapil B K Rastogi and Peush Chaudhary (2015) Magnetotelluirc investigations in Kachchh region for identification of faults and crustal structure, ISR Annual Report 2014-15, www.isr.gujarat.gov.in, pp. 29-31

Mohan, Kapil, Peush Chaudhary, Pavan Gayatri, Virander Choudhary, Pruthul Patel, Mehul Nagar and Rastogi B K (2015) MT study over Chabsar and Tuwa hot water spring region for identification of geothermal source zone, ISR Annual Report 2014-15, www.isr.gujarat.gov.in, pp. 3134

Mohanty W K and Walling M Y (2008) First order seismic microzonation of Haldia, Bengal Basin (India) using a GIS Platform PAGEOPH 165 1325-1350

Mohanty W K and Walling M Y (2009) Seismic Hazard in mega city Kolkata, India, Natural Hazards, DOI: 10.1007/s11069

Mohanty W K, Rajesh P, Suresh G, Shukla A K, Walling M Y and Srivastava J P (2009c) Estimation of Coda wave attenuation for the National Capital Region, Delhi, India, using local earthquakes PAGEOPH 166 429-449

Mohanty W K, Walling M Y, Nath S K, Mitra S and John A (2009b) Microtremor survey in Talchir, India to ascertain its basin Characteristics in terms of predominant frequency by Nakamura H/V ratio technique Engg Geol 106 123-132

Mohanty W K, Walling M Y, Vaccari F and Tripathy T P (2009a) G.F. Modelling of SH- and P-SV-wave fields and seismic microzonation based on response spectra for Talchir basin, India Engg Geol 104 84-97

Mohapatra A K and Mohanty W K (2011) Coda Q (Qc) Estimates in the North East (NE) India using Local Earthquakes Seismol Res Lettrs 82 150-156

Mukhopadhyay B and Dasgupta S (2008) Swarms in Andaman Sea, India - a seismotectonic analysis Acta Geophysica 56 1000-1014 DOI: 10.2478/s11600-008-0039-5

Mukhopadhyay B, Acharyya A and Dasgupta S (2008) Statistical Analysis on Yearly Seismic Moment Release Data to Demarcate the Source Zone for an Impending Earthquake in the Himalaya Acta Geophysica 57 387-399 DOI: 10.2478/s11600-008-0068-0

Mukhopadhyay B, Acharyya A and Dasgupta S (2010b) Potential Source Zones for Himalayan Earthquake: Constraints from Spatial-temporal Clusters Natural Hazards DOI: 10.1007/ s11069-010-9618-2

Mukhopadhyay B, Acharyya A, Bhattacharya A, Dasgupta S and Sengupta S R (2009) Revisiting The Andaman Subduction Lithosphere Following The 26 December 2004 Sumatra Earthquake Ind Jour Geosci 63 1-10

Mukhopadhyay B, Acharyya A, Mukhopadhyay M and Dasgupta S (2010c) Relationship between earthquake swarm, rifting history, magmatism and pore pressure diffusion - an example from South Andaman Sea, India Jour Geol Soc Ind 76 164-170

Mukhopadhyay B, Dasgupta S and Acharyya A (2010d) Seasonal bias for the occurrence of shallow-focus earthquakes in the Indian tropics Ind Jour Geosci 63 327-332

Mukhopadhyay B, Fnais M, Mukhopadhyay M and Dasgupta S (2010) Seismic cluster analysis for the Burmese-Andaman and West Sunda Arc: Insight into subduction kinematics and seismic potentiality', Geomatics Natural Hazards and Risk DOI: 10.1080/19475705.2010.494014

Mukhopadhyay S, Kumar A, Garg A, Del-Pezzo E and Kayal J R (2014) The Attenuation Mechanism of S-Waves in the Source Zone of the 1999 Chamoli Earthquake J Asian Earth Sci 79 446-454

Mukul M, Jade S, Bhattacharyya A K and Bhusan K (2010) Crustal shortening in convergent Orogens: Insights from global positioning system (GPS) Measurements in Northeast India Journal of Geological Society of India 75 302-312 
Nath S K and Thingbaijam K K S (2009) Seismic hazard assessment - A holistic microzonation approach Natural Hazds and Earth Syst Sci 19 1445-1459

Nath S K and Thingbaijam K K S (2010) Assessment of Seismic Site Condition: a Case Study from Guwahati city, Northeast India [Online: DOI 10.1007/s00024-010-0197-7], 00024010-0197-7

Nath S K and Thingbaijam K K S (2011) Peak Ground Motion Predictions in India: An appraisal for rock sites Jour Seismol 15 295-315

Nath S K and Thingbaijam K K S (2012) Probabilistic Seismic Hazard Assessment of India Seism Res Lett 83 135-149

Nath S K, Adhikari M D, Maiti S K, Devaraj N, Srivastava N and Mohapatra LD (2014) Earthquake scenario in West Bengal with emphasis on seismic hazard microzonation of the city of Kolkata, India, Nat Haz and Earth System Sci 14 2549-2575 doi: 10.5194/nhess-14-2549-(2014)

Nath S K, Raj A, Kumar A and Thingbaijam K K S (2009) Ground Motion Synthesis and Seismic Scenario in Guwahati City : A Stochastic Approach Seismol Res Letts 80 233-242

Nath S K, Raj A, Sharma J, Thingbaijam K K S, Kumar A, Nandy D R, Yadav M K, Dasgupta S, Majumdar K, Kayal J R, Shukla A K, Deb S K, Pathak J, Hazarika P J, Paul D K and Bansal B K (2008a) Site Amplification, Qs and Source Parameterization in Guwahati Region from Seismic and Geotechnical Analysis Seismol Res Letts 79 526-539

Nath S K, Roy D and Thingbaijam K K S (2008b) Disaster Mitigation and Management for West Bengal, India an Appraisal Curr Sci 94 858-866

Nath S K, Shukla K and Vyas (2008c) Seismic Hazard Scenario and Attenuation Model of the Garhwal Himalaya using Near Field Synthesis from Weak Motion Seismometry Jour Earth Syst Sci 117 649-670

Nath S K, Thingbaijam K K S, Adhikari M D, Devraj N, Nayak A, Ghosh S K and Mahajan A K (2013) Topographic gradient based site characterization in India complemented by strong ground motion spectral attributes Soil Dyn Earthquake Engg 55 233-246

Nath S K, Thingbaijam K K S, Vyas J C, Prakash Dev S M S and Sengupta P (2010) Macroseismic-driven Site Effects in the Southern Territory of West Bengal Seismol Res Lettrs $81480-487$

Nath S K, Thingbaijam K K. Singh and Raj A (2008d) Earthquake Hazard in the Northeast India - A Seismic Microzonation Approach with Typical Case Studies from Sikkim Himalaya and Guwahati city Jour Earth Syst Sci 117 809831
Nath S K,Thingbaijam K K S, Maiti S K and Nayak A (2012) Ground motion prediction equation in Shillong region, northeast India J Seism doi: 10.1007/s10950-012-9285-8

Nayak A, Nath S K, Thingbaijam K K S and Baruah S (2011) New Insights into Path Attenuation of Ground Motions in NE India and NW Himalayas Bull Seism Soc Am 101 2550-2560

Nayak A, Nath S K, Thingbaijam K K S and Baruah S (2011) New Insights into Path Attenuation of Ground Motions in NE India and NW Himalayas Bull Seis Soc Amer 101 $2550-2560$

Nayak S (2011) "Foreword" on Seismic Microzonation Handbook, Geoscience Division, Ministry of Earth Sciences, Government of India, p. 518

Nayak S and Srinivasa Kumar T (2008) The First Tsunami Early Warning Centre in the Indian Ocean. In 'Risc Wise', Tudor Rose, UK. p. 175-177

Oreshin S I, Vinnik L P, Kiselev S G, Rai S S, Prakasam K S and Treussov A V (2011) Deep seismic structure of the Indian shield, western Himalaya, Ladakh and Tibet Earth Planet Sci Lett 307 415-429

Padhy S and Subhadra N (2013) Separation of intrinsic and scattering seismic wave attenuation in Northeast India Geophy J Int 195 1892-1903

Padhy S, Mishra O P, Zhao D and Wei W (2011) Crustal heterogeneity in the 2007 Noto-Hanto earthquake area and its geodynamical implications Tectonophysics $\mathbf{5 0 9} 55$ 68

Padhy S, Subhadra N and Kayal J R (2011) Frequency dependent body and coda waves in Andaman Sea basin Bull Seism Soc Am 101 doi: 10.1785/0120100032

Padhy S, Takemura S, Takemoto T, Maeda T and Furumura T (2013) Spatial and Temporal Variations in Coda Attenuation Associated with the (2011) Off the Pacific Coast of Tohoku, Japan (Mw 9) Earthquake Bull Seism Soc Am 103 14111428

Pal I, Nath Shukla S K, Pal D K, Raj A, Thingbaijam K K S and Bansal B K (2008) Earthquake Hazard Zonation of Sikkim Himalaya using a GIS Platform Natural Hazards 45 333377

Panthi A, Shankar D, Singh H N and Kumar A (2011) Time predictable model applicability for earthquake occurrence in Northeast India and vicinity Jour Nat Hazds Earth Syst Sci 11 993-1002

Parvez I A and Lyubushin A A (2010) Map of seismic hazard of India using Bayesian approach Natural Hazards 55 543556 
Parvez I A, Romanelli F and Panza G F (2011) Long Period Ground Motion at Bedrock Level in Delhi City from Himalayan Earthquake Scenarios PAGEOPH 168 409-477

Paudyal H, Shanker D and Singh H N (2011) Characteristics of Earthquake Sequence in Northern Himalayan Region of South Central Tibet - Precursor Search and Location of Potential Area of future earthquake J Asian Earth Sci 41 459-466 doi: 10.1016/j.jseaes.2010.11.019

Paudyal H, Shanker D, Singh H N, Kumar A, Panthi A and Singh V P (2010) Current understanding of the seismotectonicsof Western Nepal Himalaya and vicinity Acta Geod Geophy Hung 45 195-209 DOI: 10.1556/AGeod. 45.2010.2.5

Pinki Hazarika and Ravi Kumar M (2012) Seismicity and source parameters of moderate earthquakes in Sikkim Himalaya Nat Haz 62 937-952

Raghukanth S T G (2010a) Estimation of Seismicity Parameters for India Seismol Res Letts 81 207-217

Raghukanth S T G (2010b) Comments on Estimation of Seismicity Parameters for India (Seismol Res Lettrs 2010, $81207-$ 217) by Nath S K and Thingbaijam K K S, Seismol Res Letts 81 1001-1003

Raghukanth S T G and Dash S K (2010) Deterministic seismic scenarios for North East India Jour Seismol 14 143-167 DOI: $10.1007 / \mathrm{s} 10950-009-9158-y$

Rai A, Gaur V K, Rai S S and Priestley K F (2009) Geophy Jour Internat 176 518-528

Rai S S, Borah K, Das R Gupta S, Srivastava S, Prakasam K S, Sivaram K, Kumar S and Meena R (2013) The South India Precambrian crust and shallow lithospheric mantle: Initial results from the India Deep Earth Imaging Experiment Earth Sys Sci 122 1435-1453

Raj A, Nath S K and Thingbaijam K K S (2008) A Note on the Recent Earthquakes in the Bengal Basin Curr Sci 951127 1131

Raj A, Nath S K, Bansal B K, Thingbaijam K K S, Kumar A, Thiruvengadam N, Yadav A and Arrawatia M L (2009) RapidEstimation of Source Parameters using Finite Fault Modeling -A Case of Sikkim and Garhwal Himalaya Seisol Res Lett 80 89-96

Rajendran C P, John B, Sreekumari K and Rajendran K (2009) Reassessing the earthquake hazard in Kerala based on the historical and current seismicity Jour Geol Soc Ind $\mathbf{7 3}$ 785-802

Rajendran C P, Rajendran K, Thakkar M and Goyal B (2008) Assessing the previous activity at the source zone of the 2001 Bhuj earthquake based on the near-source and distant paleoseismological indicators Jour Geophys Res 113
B05311 doi: 10.1029/2006JB004845

Rajendran C P, Ramanamurthy M V, Reddy N T and Rajendran K (2008) The hazard implications of the late arrival of the 1945 Makran tsunami Curr Sci 95 1739-1743

Rajendran K and Rajendran C P (2011) Revisiting some significant earthquake sources in the Himalaya: Perspectives on past seismicity Tectonophysics $\mathbf{5 0 4}$ 75-88

Rajendran K, Andrade V and Rajendran C P (2011) The June 2010 Nicobar Earthquake: Fault Reactivation on the Subducting Oceanic Plate Bull Seismol Soc Amer 101 25682577

Rajendran K, Andrade V, Thulasiraman N and Rajendran C P (2011) The 11 March 2011 Tohoku (Sendai), Japan earthquake Curr Sci 100 966-969

Rajendran K, Rajendran C P, Thulasiraman N, Andrews R and Sherpa N (2011) The 18 September 2011, North Sikkim earthquake Curr Sci 101 1475-1479

Rao Ch Nagabhushana, Rao N, Purnachandra and Rastogi B K (2013) Evidence for right-lateral strike-slip environment in the Kutch basin of northwestern India from moment tensor inversion studies J Asian Earth Sci 64 158-167 doi: 10.1016/j.jseaes.(2012).12.012

Rao K M, Kumar M R, Singh A, Rastogi B K (2013) Two distinct shear wave splitting directions in the northwestern Deccan Volcanic Province Solid Earth 118 5487-5499

Rastogi B K and Mandal P (1999) Foreshocks and Nucleation of small to moderate size Koyna earthquakes (India) Bull Seis Soc Am 89 829-836

Rastogi B K (2010) Causative Mechanisms of the Intraplate Earthquakes Occurring in India Advances in Geosciences 26 97-116

Rastogi B K, Kumar Santosh, Aggrawal Sandeep K, Kapil Mohan, Nagabhushan Rao N, Purnachandra Rao and Girish Chandra Kothyari (2013) The October 202011 M-w 5.1 Talala earthquake in the stable continental region of India Nat Haz 65 1197-1216 doi: 10.1007/s11069-012-0226-1, 65 1197-1216

Rastogi B K, Prantik Mandal and Biswas S K (2014) Seismogenesis of earthquakes occurring in the ancient rift basin of Kachchh, Western India, In: Intraplate Earthquakes, (Ed. Pradeep Talwani) Cambridge Univ Press 126-161

Rastogi B K, Singh AP, Sairam B, Jain S K, Kaneko F, Segawa S and Matsuo J (2011) The Possibility of Site Effects: the Anjar Case, Following the Past Earthquakes in the Gujarat, India Seismol Res Letts 82 692-701 DOI: 10.1785/ gssrl.82.1.692 
Rastogi B K,Choudhury P, Dumka R, Sreejith K M and Majumdar T J (2012) Stress pulse migration by viscoelastic process for long-distance delayed triggering of shocks in Gujarat, India, after the $2001 \mathrm{Mw} 7.7$ Bhuj earthquake, in Extreme Events and Natural hazards: The Complexity Perspective Geophys Monograph Ser 196 edited by Sharma A S et al. 63-73, AGU, Wahington, D. C., DOI: 10.1029/ $2011 \mathrm{GM} 001061$

Reddy C D et al. (2012) Far-reaching transient deformation following the Bhuj earthquake reveals viscoelastic flow in the mantle with only modest contributions from crustal relaxation process Natural Hazards

Reddy D V and Nagabhushanam P (2012) Chemical and isotopic seismic precursory signatures in deep groundwater: Cause and effect Appl Geochem 27 2348-2355 doi: 10. 1016/ j.apgeochem.(2012).08.023

Roy Sunil Kumar, Srinagesh D and Saikia Dipankar et al. (2012) Seismic anisotropy beneath the Eastern Dharwar craton Lithosphere 4 259-268 doi: 10.1130/L198.1

Roy, Sohini, Ghosh, Uma, Hazra S and Kayal J R (2012) Fractal Dimension and $b$ Value Mapping Before and After the 2004 Megathrust Earthquake in the Andaman-Sumatra Subduction Zone Geophy Monograph AGU Pub doi: 10.1029/(2011)GM 001072

Saha D K, Nasker D C, Bhattacharya P M and Kayal J R (2007) Geophysical and Seismological investigation for the hidden Oldham fault in Shillong plateau and Assam valley of northeast India Jour Geol Soc Ind 69 359-372

Saikia D, Kumar M R, Singh A, Mohan G A and Dattatrayam R S (2010) Seismic anisotropy beneath the Indian continent from splitting of direct S waves Jour Geoph Res 115 doi: $10.1029 / 20$

Schiffman C, Bali B S, Szeliga W and Bilham R (2013) Seismic slip deficit in the Kashmir Himalaya from GPS observations Geophysical Research Letters 405642 5645 doi: 10.1002/2013GL057700

Sen G, Bizimis M, Das R, Paul D K, Ray A and Biswas S K (2009) Deccan plume, lithospheric rifting, and volcanism in Kutch, India Earth and Planetary Science Letters 277 101-111

Sengupta P, Nath S K, Thingbaijam K K S and Mistri S (2011) Fractal Analysis of Major Faults in India on a Regional Scale Jour Geol Soc Ind 78 226-232

Shanker D, Singh H N, Paudyal H, Kumar A, Panthi A and Singh V P (2010) Searching for an Earthquake Precursor- A Case Study of Precursory Swarm as a Real Seismic Pattern before Major Shocks PAGEOPH 167 655-666 DOI: 10.1007/s00024-010-0067-3
Sharma, Babita, Gupta A K, Kameshwaridevi D, Kumar D, Teotia S S and Rastogi B K (2008) Attenuation of high frequency seismic wave in Kachchh region, Gujarat, India Bull Seism Soc Amer 98 2325-2346

Sharma, Babita, Teotia S S and Kumar D (2007) Attenuation of P and S-waves in Koyna region Jour Seismol 11 327-344

Shashidhar D, Rao N P, Srinagesh D, Gupta H, Satyanarayana H V S, Suresh G and Satish A (2013) The 14 April (2012) Koyna Earthquake of Mw 4.8: insights into active tectonics of the Koyna region J Seism 17 1345-1353

Singh A P, Mishra O P, Kumar D, Kumar S and Yadav R B S (2011) Spatial variation of aftershocks activity across the Kachchh rift Basin and its Seismotectonic Implications Jour Earth Syst Sci 121 439-451

Singh A P, Mishra O P, Rastogi B K and Kumar D (2011) 3-D Seismic Structure of the Kachchh, Gujarat and Its Implications for the Earthquake Hazard Mitigation Natural Hazards 57 83-105 DOI: 10.1007/s11069-010-9707-2

Singh AP, Roy I G, Kumar S and Kayal J R (2013) Seismic source characteristics in Kachchh and Saurashtra regions of Western India: b-value and fractal dimension mapping of aftershock sequences Nat Haz doi: 10.1007/s11069-0130843-3

Singh A, Kumar M R and Raju P S (2010) Seismic structure of the underthrusting Indian crust in Sikkim Himalaya Tectonics 29 doi: $10.1029 / 2010$

Singh A, Kumar M R, Kumar N, Saikia D, Raju P S, Srinagesh D, Rao N P and Sarkar D (2012) Seismic signatures of an altered crust and a normal transition zone structure beneath the Godavari rift Precambrian Res 220-221 1-8 http:// dx.doi.org/10.1016/j.precamres.2012.07.006

Singh A, Mercier J P, Ravi Kumar M, Srinagesh D, Chadha R K (2014) Continental scale body wave tomography of India: evidence for attrition and preservation of lithospheric roots Geochem Geophys Geosyst 15 658-675. http://dx.doi.org/ 10.1002/2013GC005056

Singh Arun, Chandrani Singh and Kennet B L N (2015) A review of crust and upper mantle structurebeneath the Indian subcontinent Tectonophys 644-645 1-12

Singh Arun, Kumar M Ravi and Srinagesh D (2013) Near-Surface Shear Velocities in Diverse Geological Segments of India Bull Seism Soc Am 103 317-327 doi: 10.1785/ 01201(2011)2

Singh C and Chadha R K (2010) Variations in the frequency magnitude distribution with depth in the Koyna, Reservoir site, India Jour Asian Earth Sci 39 331-334

Singh C, Bhattacharya P M and Chadha R K (2008) Seismicity in Koyna-Warna reservoir site in the western India: Fractal 
and b value mapping Bull Seism Soc Amer doi: 1785/ 0120070165

Singh Chandrani, Arun singh, Mukhopadhyay S, Shekar M and Chadha R K (2011) Lg Attenuation characteristics across the Indian Shield Bull Seismol Soc Am 101 2561-2567 doi: $10.1785 / 0120100239$

Singh Chandrani, Bharathi V K Srinivasa and Chadha R K (2012) Lapse time and frequency-dependent attenuation characteristics of Kumaun Himalaya J Asian Earth Sci 5455 64-71 doi: 10.1016/j.jseaes.(2012).03.014

Singh Chandrani, Shekar M and Singh Arun et al. (2012) Seismic Attenuation Characteristics along the Hi-CLIMB Profile in Tibet from Lg Q Inversion: Bull Seism Soc Am 102 2796-2796, doi:10.1785/01(2012)0220

Singh Chandrani, Shekar M, Arun Singh and Chadha R K (2012) Seismic attenuation characteristics along Hi-CLIMB profile in Tibet from Lg inversion Bull Seism Soc Am 102 783-789 doi: 10.1785/01(2011)0145

Singh Chandrani, Singh, Arun, Bharathi V K Srinivasa Bansal AR and Chadha R K (2012) Frequency dependent body wave attenuation characteristics in the Kumaun Himalaya Tectonophysics doi: 10.1016/ j.tecto.(2011).12.013

Singh Chandrani, Srinivasa Bharathi V K and Chadha R K (2012) Lapse time and frequency-dependent attenuation characteristics of Kumaun Himalaya J Asian Earth Sci doi: 10.1016/j.jseaes.(2012).03.014

Singh H N, Paudyal H, Shanker D, Panthi A, Kumar A and Singh V P (2010) Anomalous Seismicity and Earthquake Forecast in Western Nepal Himalaya and its Adjoining Indian Region PAGEOPH 167 667-684 DOI: 10.1007/s00024-010-00726

Singh O P, Chowdhuri S N and Gaonkar S G (2008) Site response study in the eastern part of Guwahati city (Assam), using ambient seismic noise Specl Issue Indian Minerals 61 141148

Singha Roy P N and Nath S K (2007) Precursory Correlation Dimensions for three Great Earthquakes by Curr Sci $\mathbf{9 3}$ 1522-1529

Sivaram K, Kumar D, Teotia S S, Rai S S and Prakasam K S (2013) Source parameters and scaling relations for small earthquakes in Kumaon Himalaya, India J Seism 17 579592

Sivaram K, Mahesh P and Rai S S (2011) Stability Assessment and Quantitative Evaluation of H/V Spectral Ratios for Site Response Studies in Kumaon Himalaya, India Using Ambient Noise Recorded by a Broadband Seismograph Network Pure Appl Geophys 169 1801-1820 doi: 10.1007/ s00024-011-0436-6
Srijayanthi G, Kumar M Ravi and Sirisha T et al. (2012) The ISLANDS Network in the Andaman-Nicobar Subduction Zone Seism Res Lett 83 686-696 doi:10.1785/ 02(2011) 0143

Srikanth T, Pradeep R K, Singh A P, Rastogi B K and Kumar S (2010) Earthquake Vulnerability Assessment of Existing Buildings in Gandhidham and Adipur Cities, Kachchh, Gujarat (India) European Journal of Scientific Research ISSN 1450-216X 41 336-353

Srinagesh D, Singh S K, Chadha R K, Paul A, Suresh G, Ordaz and Dattatrayam R S (2011) Amplification of seismic waves in the central Indo-Gangetic Basin, India Bull Seismol Soc Am 101 2231-2242 doi: 10.1785/0120100327

Srinivas D, Srinagesh D, Chadha R K and Kumar M R (2013) Sedimentary Thickness Variations in the Indo-Gangetic Foredeep from Inversion of Receiver Functions Bull Seism Soc Am 103 2257-2265

Srivastava H N, Verma M and Bansal B K (2010) Seismological constraints for the 1905 Kangra earthquake and associated hazard in northwest India Curr Sci 99 1549-1559

Swaroopa Rani V, Kirti Srivastava, Srinagesh D and Dimri V P (2011) Spatial and Temporal variations of $b$ value and fractal dimension for Makran region Marine Geodesy 34 77-82 doi: 10.1081/01490419.(2011).547804

Thingbaijam K K S, Chingtham P and Nath S K (2009) Seismicity in the Northwest Frontier Province of Indian-Eurasian Plate Convergences Seismol Res Letts 80 599-608

Thingbaijam K K S, Nath S K, Yadav A, Raj A, Walling M Y and Mohanty W K (2008) Recent Seismicity in Northeast India and its Adjoining Region Jour Seismol 12 107-123

Vaccari F, Walling M Y, Mohanty W K, Nath S K, Verma A K, Sengupta A and Panza G F (2011) Site-specific modeling of SH and P-SV waves for microzonation study of Kolkata metropolitan city, India PAGEOPH 168 67-91

Walling M Y and Mohanty W K (2009) An overview on the seismic zonation and microzonation studies in India Earth Science Reviews 96 67-91

Walling M Y, Mohanty W K, Nath S K, Mitra S and John A (2009) Microtremor survey in Talchir India to ascertain its basin characteristics in terms of predominant frequency by Nakamura spectral ratio technique Engg Geol 106123 13

Wang Z, Fukao Y, Zhao D, Kodiara S, Mishra O P and Yamada A (2009) Structural heterogeneities in the crust and upper mantle beneath Taiwan Tectonophysics 476 460-477 doi: 10.1016/j.tecto.2009.07.018

Wang Z, Zhao D, Huang R, Tang S and Mishra O P (2009) 
Structural Heterogeneity in Northeast Japan and Its Implications for the Genesis of the 2004 and 2007 Niigata Earthquakes Bull Seism Soc Amer 99 doi: 10.1785/ 012008281

Wenjin Zhao, Prakash Kumar, James Mechie, Rainer Kind, Rolf Meissner, Zhenhan Wu and Danian Shi, 165 Annual Report (2011)-12 Appendixes Heping Su, Guangqi Xue, Marianne Karplus and Frederik Tilmann, (2011) - Tibetan plate overriding the Asian plate in central and northern Tibet, Nature Geoscience, doi: 10.1038/ngeo1309 4 870-873

Yadav A, Shashidhar D, Mallika K, Rao N P, Rohilla S, Satyanarayana H V S, Srinagesh D and Gupta H (2013) Source parameters of earthquakes in the reservoir-triggered seismic (RTS) zone of Koyna-Warna, Western India Nat Haz, 69 965-979

Yadav R B S, Bayrak T, Tripathi J N, Chopra S, Singh A P and Bayrak E (2011) A Probabilistic Assessment of Earthquake Hazard Pramaters in NW Himalaya and the Adjoining Regions PAGEOPH DOI: 10.1007/s00024-011-0434-8
Yadav R B S, Gahalaut V K, Sumer Chopra and Bin Shan (2012) Tectonic Implications and Seismicity Triggering During the 2008 Baluchistan, Pakistan Earthquake Sequence $J$ Asian Earth Sci 45 167-178

Yadav R B S, Papadimitriou E E, Karakostas V G, Shanker D, Rastogi B K, Chopra S, Singh AP and Kumar S (2011) The 2007 Talala, Saurashtra, Western India Earthquake Sequence: Tectonic Implications and Seismicity Triggering Jour Asian Earth Sci 40 303-314 DOI: 10.1016/j.jseaes. 2010.07.001

Yadav R B, Shankar S D, Chopra S and Singh A P (2010) An Application of Regional Time and Magnitude Predictable Model for Long-Term Earthquake prediction in the vicinity of October 8, 2005 Kashmir Himalaya earthquake Natural Hazards 54 985-1014 DOI: 10.2007/s11069-010-9519-4

Yadav R K, Kundu B, Gahalaut K, Catherine J, Gahalaut V K, Ambikapthy A and Naidu M S (2013) Coseismic offsets due to the 11 April (2012) Indian Ocean earthquakes (Mw 8.6 and 8.2) derived from GPS measurements Geophy Res Lett 40 3389-3393, Article 10.1002/grl.50601. 